\title{
RELATIONS BETWEEN MORPHOLOGICAL VARIABLES AND NORMAL AND PATHOLOGICAL CONATIVE CHARACTERISTICS OF HANDBALL PLAYERS
}

\author{
Veroljub Stanković ${ }^{1}$, Julijan Malacko ${ }^{2}$, Ivana Bojić ${ }^{3}$, and Jelena Ilić ${ }^{4}$ \\ ${ }^{1}$ Faculty of Sport and Physical Education, University of Priština, Serbia \\ ${ }^{2}$ Faculty of Sport and Physical Education, University of Novi Sad, Serbia \\ ${ }^{3}$ Faculty of Sport and Physical Education, University of Niš, Serbia \\ ${ }^{4}$ Institute for Sport and Sports Medicine of the Republic of Serbia, Belgrade, Serbia
}

\begin{abstract}
SUMMARY
The aim of the research was to study the relations between morphological, normal and pathological conative characteristics of handball players of the Premiere Handball League of Serbia. The study was based on a system of 51 variables (23 anthropometric, 16 normal conative and 12 pathological conative variables). The data were collected on a suitable sample $(N=71)$ and processed using a canonical correlation analysis. The results indicate that there is a canonical correlation between the systems of anthropometric variables and the system of normal conative characteristics $\left(R_{c}=.80 ; p<.00\right)$, and that there were two statistically significant correlations between the system of normal and pathological conative characteristics $\left(R_{c}=.69 ; \mathrm{p}<.00\right.$ i $\left.\mathrm{R}_{c}=.62 ; p<.02\right)$. The handball players of the ectomesomorph type are characterized at the one end with longitudinal measures and on the other with transversal dimensionality, the volume of the femoral region if they have increased values of conative variables, are extrovert and non-anxious. Among the handball players who are polite and considerate of each other there is an increase in the scores for depression as well as those which indicate a more pronounced vivacity and impulsiveness and expressiveness. Handball players who more frequently manifest dominant, competitive or even aggressive behavior are more anxious, while those who are more moral and adhere more to the rules are more prone to hypersensitivity. The ones who are undaunted and have an adventurous spirit score higher for obsession. Tense, energetic and impatient handball players often develop gastrointestinal conversion, hypochondria and phobias.
\end{abstract}

Key Words: conative relations, morphology, handball, Serbia.

\section{INTRODUCTION}

Handball is a very demanding contact team sport which in its structure contains elementary movements such as running, jumping, sprint, arm swings, hits, blocks, pushing along with interactive contact with the opponent during the game (Vrbik, Čižmek, \& Gruić, 2011). Handball success depends on a great number of external and internal factors. According to some authors (Gabrijelić, 1977; Ilić, 1993; Pokrajac, 1983), in the equation of the specification of sports results, as many as 13 factors have to be taken into consideration 13 (morphological, motor, functional, conative, cognitive, motivational, sociological, health etc.).
Even though the morphological characteristics of the anthropological status of a man usually include the processes of growth and ontogenetic development, it is based on the interaction between all the anthropological morphological characteristics and to a significant extent is determined by endogenously and exogenously conditioned factors. There is a significant body of research which deals with the morphological characteristics of handball players (Popović-Ilić, Stanković, Vitošević, \& Ilić, 2010; Srhoj, Marinović, \& Rogulj, 2002; Šentija, Matković, Vuleta, Tomljanović, \& Džaj, 1997; Šibila \& Pori, 2009; Vrbik et al., 2011), as well as the relations between their anthropometric and psychological characteristics. Within them, the 
identification of latent variables in the morphological space was carried out with the help of factor analysis, along with the increased use of taxonomy (cluster) algorithms, with the primary aim of determining the morphological structure of the human body, then the relations between these characteristics and other anthropological features, abilities and characteristics, as well as how much they contribute to success in sport (Malacko \& Popović, 2001; Popović \& Simonović, 2008; Stanković, 2000; Stanković \& Malacko, 2008; Stanković, Malacko, \& Doder, 2011; Stanković \& Popović, 2011; Szirovicza, Momirović, Hošek, \& Gredelj, 1980).

Some of the morphological characteristics of athletes are strongly bound to success in sport (Stanković, 2001). It has been determined that in sports games, tall athletes, the ones with a greater arm and leg length have a certain advantage when compared to short athletes, or those with short extremities. Furthermore, athletes with greater amounts of fatty tissue are inferior in comparison to the ones with the same weight but unburdened by the unwanted fatty tissue. A great number of studies which deal with the transformations of morphological characteristics (Popović-Ilić et al., 2010; Srhoj et al., 2002; Šentija et al., 1997; Šibila et al., 2009; Vrbik et al., 2011) indicate their complexity considering that they are under the influence of both genetic factors as well as online factors, where we need to point out that the influence of genetic factors is not the same for all the latent morphological dimensions. The analysis of latent dimensions of morphological variables led to solutions which could taxonomically be interpreted, primarily those responsible for the growth of bones in terms of length, that is longitudinal dimensionality of the skeleton which is responsible for body mass, and circular dimensionality, subcutaneous fatty tissue and transversal dimensionality of the skeleton. It has been determined that in the case of handball players, it is possible to speak of ecto-mesomorphia. The bicristal range or second horizontal axis of the body is more responsible for a harmonious and biomechanically more functional morphological development than the first horizontal axis of the body.

In the study carried out by Stanković et al. (2009), it was determined that unlike basketball and soccer players, handball players have increased values for soft tissue, defined through the amount of muscle mass and subcutaneous fatty tissue. Regarding that, the relevant literature indicates that muscle volume has a direct influence on the ability to develop muscle strength, and thus define the possibilities of greater or lesser effective movement, overcoming resistance or obstacles. Even though subcutaneous fatty tissue in motor manifestations of athletes represents a ballast mass, it is very important not to disregard the need for the optimum amount of fatty tissue, considering the fact that it contains fatty acids which are necessary not only for the proper realization of a variety of chemical processes in the human body, but also for the structure of certain tissues and for energy production.

Conative characteristics are responsible for the modalities of human behavior and are determined as the latent structures on which the modalities of human behavior depend in relation to oneself, other people and society in general, as well as the characteristic modalities of emotional reactions and determine manner, form and stability, but not the intensity of the reaction (Pajević, 2003). Considering the fact that there are normal and pathological modalities of behavior, conative characteristics can be divided into normal and pathological. Normal conative characteristics, or factors, are usually mutually independent and normally distributed in the population. They integrate the ego and enable dynamic and effective communication with the environment. Different authors have often obtained very different results in terms of the structure of normal conative characteristics and thus, various theories of personality were also formed. The theoretical framework of this paper is Cattell's trait theory, which is based on the existence of 16 factors. Namely, Cattell (1978) thinks that personality is what tells us what a person will do when he finds himself in a certain situation. Human behavior is the product of a situation in which a man finds himself and the characteristics of his personality. Cattell sees personality as a complex and differentiated group of features with the motivation which to a great extent depends on the subgroup of dynamic features which refer to the activities of an individual when focusing on achieving a goal.

It is known that conative characteristics are connected to the decrease or increase in adaptive powers, while pathological ones cause disturbances in the integration of the personality, where the balance between the process of excitation and relaxation is interrupted, including the relative influence of disposition on most individual characteristics or groups of these characteristics of the personality. This includes the fact that they are primarily genetically conditioned (Popović \& Simonović, 2008; Powell \& Royce, 1981). They diminish the adaptation abilities of individuals and their distribution in the population is not normal considering that most people score low values on these factors (Pajević, 2003). 
However, we should add that conative regulatory mechanisms, which have the task to neutralize the consequences of various disturbances (that is, to produce adaptable behavior or emotional stability), can themselves become a disturbance the moment when they cross a certain threshold of regulation. The joint characteristic of both kinds of conative dimensions (both normal and pathological) is that they determine the forms of behavior and reaction, which they use to affect the adaptational and active effectiveness.

At the very beginning of the 20 th century, Sheldon \& Kretschmer tried to establish a typology of the personality on the basis of body constitution. Kretschmer $(1925 / 1970)$ claimed that individuals with a pyknic body type are prone to manic-depressive psychosis, while the asthenic type is characterized by a schizoid personality with a tendency of developing schizophrenia. Sheldon (Sheldon \& Stevens, 1942) claimed that with the help of a series of measuring data on body composition we can obtain a certain image on the manifestation of these factors. The morphogenotype, as a hypothetical biological makeup, which can be found in the basis of external, visible body type (phenotype) also plays an important role not only in determining physical development but also shaping behavior. The somatotype represents a compromise between the morhpogenotype and phenotype. The study of the connection between the somatotype and temperament types determined that in the case of endomorphs, we find features which characterize the viscerotome type of temperament, including a proclivity for comfort, sociability, gluttony and the desire for love and affection. They are relaxed, slow to react, balanced in their nature, tolerant and cooperative. Mesomorphs are characterized by features such as love of physical activity and a tendency for risk which is characteristic of the somatotype. This type of temperament is also characterized by aggression, insensitivity for the feelings of others, a mature look, loud behavior, courage and claustrophobia, while its basic values include action, power and imposition. Ectomorphs are characterized by hypersensitivity in comparison to the stimuli which originate from the surroundings, are introvert and find pleasure in reflection, a longing to withdraw into themselves and their solitude, which are the characteristics of the cerebrotone type of temperament, including control, stiffness, secrecy, shyness, a young spirit, fear of people, as they are happiest in small and isolated spaces. The individual reacts quickly, sleeps poorly and tries to avoid attracting attention to oneself (Hol \& Lindzi, 1983).
Herdis, Deabler, Hartl, \& Willis (1973) in their study carried out on 300 war veterans attempted to determine whether there was a connection between Sheldon's somatotypes and Cattell's personality factors. Their results indicated that endomorphic and ectomorphic somatotypes did not have a significant correlation with Cattell's personality factors. In addition to factor L, which has a positive correlation with the mesomorphic type, this type has also indicated negative statistically significant correlations (although of a very low intensity) with the factors of high/low ergic tension Q4 (calm - high strung), crystallized intelligence $B$ and the factor of ego strength C which represents emotional (in)stability. The mesomorphic ("sports") type of veteran was characterized by a greater level of suspicion, jealousy and calm, a lower level of crystallized intelligence and lower emotional stability.

The aim of this research was to evaluate whether there were any statistically significant relations between the system of morphological characteristics, normal conative characteristics and pathological conative characteristics as well as to precisely determine which anthropological characteristics successful handball players, who were able to secure a position in the Premiere League, possess.

\section{METHODS}

\section{Sample of participants}

The sample was suitable and consisted of 71 handball players of the Premiere National Handball League

\section{Measuring instruments}

In order to evaluate the morphological characteristics, the following variables were used:

Longitudinal dimensionality of the skeleton

- Body height (VIS),

- Leg length (DNO),

- Hand length (DSA),

- Foot length (DST),

- Arm length (DRU),

- Biacromial range (BIA),

Transversal dimensionality of the skeleton

- Bicristal range (BIK),

- Hand width (SSA),

- Wrist diameter (DIR),

- Elbow diameter (DIL),

- Knee diameter (DIK),

- Foot width (SST),

Circular dimensionality and body mass 
- Body mass (MAS),

- Upper arm volume (ONA),

- Lower arm volume (OPO),

- Upper leg volume (ONT),

- Lower leg volume (OPT),

- Average thorax volume (OGK),

Subcutaneous fatty tissue:

- Upper arm skinfold (KNA),

- Back skinfold (KLE),

- Armpit skinfold (KPA),

- Abdominal skinfold (KTR),

- Lower leg skinfold (KPT).

In order to evaluate the normal conative characteristics, the 16PF battery was used (Cattell, Eber, \& Tatsuoka, 1970) with first-order factors:

- Outgoing - reserved (A),

- High intelligence - low intelligence (B),

- Higher ego strength - lower ego strength $(\mathrm{C})$,

- Dominance - submissiveness (E),

- Surgency - desurgency (F),

- Stronger superego - weaker superego $(\mathrm{G})$,

- Bold (parmia) - shy (threctia) $(\mathrm{H})$,

- Tender-minded (premsia) - tough-minded (I),

- Protension (L),

- Autia (imaginative) - practical (M),

- Shrewdness - artlessness (N),

- Apprehensive (O),

- Radicalism - conservatism (Q1),

- Self-sufficiency - group dependence (Q2),

- High self-concept - low self-concept (Q3),

- Tense - relaxed (Q4).

Pathological conative characteristics were operationalized through the score for selected scales on a test of pathological conative characteristics (Momirović, 1971), C.I.-N4 - the efficiency of the regulatory system and control of organic functions $(\mathrm{HI})$ :

- Cardiovascular conversion (K10),

- Gastrointestinal conversion (G11),

- Inhibitory conversion (I7),

- Hypochondria (H13), the effectiveness of the regulatory system and the control of defensive reactions (ALPHA),

- Anxiety (A1),

- Obsession (O3),

- Hypersensitivity (S5),

- Phobias (F2), the efficiency of the regulatory system and the control of attack reactions (SIGMA),

- Impulsiveness (N14),

- Aggression (T15) and the effectiveness of the system for the coordination of regulatory functions (DELTA),
- Paranoia (P18),

- Depression (D6).

\section{Methods of data processing}

When calculating the relations between the systems of variables of morphological characteristics, normal and pathological conative characteristics, a canonical correlation analysis was used.

\section{RESULTS}

The results of the descriptive statistics for all of the variables are shown in Table 1.

After using a matrix analysis of the cross-correlations between the system of anthropometric variables and the system of normal conative variables (Table 2) we can note that there were statistically significant correlations between the pairs of variables between the moderate number of analyzed variables of the left and right set. The personality factors which did not indicate any statistically significant correlation with the set of anthropometric variables include: higher ego strength - weaker ego strength (C), stronger superego - weaker superego $(G)$, tender-minded (premsia) - tough-minded (I), while the variables from the set of anthropometric variables which did not indicate any statistically significant correlations with the personality factors of the first order included leg length (DNO), the bicristal range (BIK), foot width (SST), upper arm volume (ONA), average thorax volume (OGK), back skinfolds (KNL), lower leg skinfolds (KPT).

Later, a canonical correlational analysis was used to study the connection between the multivariate system of anthropometric variables and system of normal conative variables. It was determined that there is a statistically significant connection between these two factors $(R=.89, p<.00)$.

From the data contained in the matrix of the canonical structure of anthropometric and normal conative variables (Table 3), we can note a statistically significant correlation between anthropometric variables and the first canonical factor. The first isolated canonical factor was defined by relatively high values of statistically significant canonical correlation coefficients. Considering the fact that the structure of the first isolated canonical factor consists of the variables of foot length (DST), arm length (DRU), hand width (SSA), wrist diameter (DIR), knee diameter (DIK) and lower leg volume (OPT), it represents a combination of the ectomesomorphic sports type. The same table shows the matrix of the structure of canonical factors of normal conative variables which 
TABLE 1

Basic statistical parameters.

\begin{tabular}{|c|c|c|c|c|c|c|c|c|c|c|c|c|}
\hline \multicolumn{7}{|c|}{ Anthropometric variables } & \multicolumn{3}{|c|}{$\begin{array}{c}\text { Pathological } \\
\text { conative variables }\end{array}$} & \multicolumn{3}{|c|}{$\begin{array}{l}\text { Personality factors } \\
\text { (raw scores) }\end{array}$} \\
\hline Var. & $\mathrm{M}$ & Min & Max & $\mathrm{SD}$ & Skew. & Kurt & Var. & $\mathrm{M}$ & SD & Var. & $\mathrm{M}$ & SD \\
\hline VIS & 1815.18 & 1626 & 1960 & 62.632 & -.269 & .321 & K10 & 2.60 & 1.625 & $\mathrm{~A}$ & 12.67 & 8.724 \\
\hline $\mathrm{DNO}$ & 1032.00 & 940 & 1180 & 47.547 & .250 & .295 & G11 & .84 & 1.327 & B & 7.15 & 2.162 \\
\hline DSA & 196.09 & 170 & 235 & 11.015 & .564 & 1.323 & I7 & 1.31 & 1.293 & $\mathrm{C}$ & 16.16 & 3.492 \\
\hline DST & 279.67 & 260 & 310 & 12.664 & .817 & .560 & $\mathrm{H} 13$ & .23 & .818 & $\mathrm{E}$ & 15.43 & 4.298 \\
\hline DRU & 782.47 & 690 & 880 & 49.924 & -.211 & -.220 & A1 & .21 & .674 & $\mathrm{~F}$ & 15.33 & 3.422 \\
\hline BIA & 414.31 & 312 & 540 & 30.129 & .385 & 4.664 & O3 & .29 & .900 & G & 9.77 & 1.987 \\
\hline BIK & 299.16 & 245 & 390 & 25.861 & .731 & 2.183 & S5 & .40 & .903 & $\mathrm{H}$ & 15.62 & 3.969 \\
\hline SSA & 85.67 & 75 & 100 & 5.442 & .092 & -.362 & F2 & 1.19 & 1.489 & I & 6.57 & 3.059 \\
\hline DIR & 58.54 & 53 & 68 & 3.022 & .219 & .152 & N14 & .59 & .887 & $\mathrm{~L}$ & 10.38 & 2.963 \\
\hline DIL & 74.78 & 62 & 88 & 6.581 & .225 & -.500 & T15 & .54 & .841 & M & 10.26 & 2.699 \\
\hline DIK & 92.38 & 76 & 105 & 5.909 & .177 & -.399 & P18 & 1.45 & 1.528 & $\mathrm{~N}$ & 10.70 & 2.647 \\
\hline SST & 92.22 & 69 & 110 & 7.878 & -.407 & .608 & D6 & 1.14 & .682 & $\mathrm{O}$ & 10.21 & 3.193 \\
\hline MAS & 788.52 & 550 & 1080 & 110.893 & .426 & -.286 & & & & Q1 & 9.19 & 2.974 \\
\hline ONA & 283.38 & 230 & 370 & 25.285 & .745 & .940 & & & & Q2 & 10.11 & 2.733 \\
\hline OPO & 269.15 & 220 & 320 & 21.027 & .275 & -.050 & & & & Q3 & 12.64 & 2.844 \\
\hline ONT & 561.83 & 480 & 680 & 45.428 & .653 & -.066 & & & & Q4 & 9.95 & 3.852 \\
\hline OPT & 392.25 & 320 & 600 & 48.820 & 2.097 & 6.215 & & & & & & \\
\hline OGK & 956.62 & 840 & 1110 & 69.548 & .249 & -.717 & & & & & & \\
\hline $\mathrm{KNN}$ & 94.01 & 36 & 198 & 36.395 & .940 & .687 & & & & & & \\
\hline $\mathrm{KNL}$ & 104.93 & 66 & 214 & 33.835 & 1.695 & 2.805 & & & & & & \\
\hline KNP & 75.46 & 46 & 162 & 23.521 & 1.474 & 2.679 & & & & & & \\
\hline KNT & 116.57 & 50 & 432 & 62.879 & 2.547 & 9.261 & & & & & & \\
\hline KPT & 102.88 & 35 & 256 & 48.759 & .821 & .517 & & & & & & \\
\hline
\end{tabular}

Legend: Var. - Variables; Min - Minimum; Max - Maximum; $M$ - Sample mean; SD - Standard deviation; Skew. - Skewnis; Kurt. - Kurtosis.

indicate that there is a very high correlation between the applied variables and the canonical factors. Considering that the isolated canonical factor represents seven conative variables: affectia - sizia (A), high intelligence - low intelligence (B), bold (parmia) - shy $(\mathrm{H})$, tender-minded (premsia) - tough-minded (I), protension (L), self-sufficiency - group adherence $(\mathrm{Q} 2)$, tense - relaxed $(\mathrm{Q} 4)$, it is clear that we are dealing with a single complex factor.

Based on the analysis of the cross-correlation matrix between the system of normal and system of pathological conative characteristics (Table 4) we can also note statistically significant correlations between pairs of variables of one and the other anthropological space. Statistically significant correlations between normal and pathological conative characteristics were determined for the following variables: affectia - sizia (A) and depression (D6); dominance - submissiveness (E) and cardiovascular conversion (K10), gastrointestinal conversion (G11), inhibitory conversion (I7), anxiety (A1); surgency - desurgency (F) and depression (D6); stronger superego - weaker superego $(\mathrm{G})$ and hypersensitivity (S5); bold - shy (H) and obsession (O3); protension (L) and cardiovascular conversion (K10); shrewdness - artlessness (N) and inhibitory conversion (I7), anxiety (A1), phobia (F2) and impulsivity (N14); apprehensive (O) and aggression (T15); radicalism - conservatism (Q1) and hypochondria (H13), obsession (O3), paranoia (P18); self-sufficiency - group-adherence (Q2) and obsession (O3); high self-concept - low self-concept (Q3) and gastrointestinal conversion (G11), inhibitory conversion (I7), impulsiveness (N14); tense - relaxed 
TABLE 2

The cross-correlations between anthropometric and normal conative variables.

\begin{tabular}{|c|c|c|c|c|c|c|c|c|c|c|c|c|c|c|c|c|}
\hline & 11 & D & C & $\mathrm{E}$ & $\mathrm{F}$ & $\bar{G}$ & $\mathrm{H}$ & 1 & $\mathrm{~L}$ & $\mathrm{M}$ & $N$ & 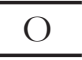 & 21 & $\mathrm{Q} 2$ & 23 & $2^{4}$ \\
\hline VIS & .05 & .12 & -.09 & -.04 & -.31 & -.12 & .05 & .04 & .03 & .10 & .08 & .02 & .08 & .19 & 10 & -.02 \\
\hline & 7 & 88 & -.18 & -.05 & .23 & -.03 & .09 & .12 & .11 & .02 & 8 & 06 & 03 & 21 & 22 & .00 \\
\hline SA & .09 & 02 & 11 & -.09 & -.10 & -.13 & 91 & .07 & .02 & .24 & 31 & 02 & 10 & 22 & 23 & -.02 \\
\hline D & .20 & .13 & .05 & 01 & -.07 & -.08 & .28 & .22 & .28 & .09 & & .12 & 6 & -.00 & 11 & .16 \\
\hline DR & .26 & 4 & 2 & 4 & -.01 & .00 & .23 & .21 & 4 & .05 & 8 & .02 & 2 & .06 & .01 & -.06 \\
\hline BIA & .1 & 01 & -.10 & -.30 & -.16 & .07 & -.15 & -.04 & -.08 & .05 & -.12 & .06 & -.07 & -.23 & -.07 & -.10 \\
\hline & 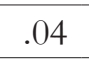 & .00 & -.00 & -.05 & -.02 & -.05 & .12 & -.05 & 02 & -.03 & -.03 & -.05 & -.05 & -.00 & .03 & -.00 \\
\hline SSA & 3 & -.19 & .17 & -.09 & -.05 & -.14 & .10 & .06 & -.02 & .12 & -.32 & .04 & .11 & -.24 & -.27 & -.15 \\
\hline IR & .06 & -.27 & .09 & -.11 & .00 & -.05 & -.04 & .02 & -.02 & .30 & -.08 & -.03 & .01 & -.14 & .22 & -.37 \\
\hline & & & 2 & & -.16 & 0 & & .05 & & .06 & & & 19) & 1 & 8 & -.17 \\
\hline DIK & 36 & -.41 & -.09 & .18 & -.00 & .02 & -.09 & .14 & .14 & .04 & .07 & .10 & .36 & .01 & -.01 & .04 \\
\hline $\mathrm{T}$ & .08 & -.04 & .05 & .13 & .13 & -.06 & .00 & -.12 & .21 & .00 & .12 & -.08 & -.03 & -.00 & .10 & .08 \\
\hline & & & -.04 & -.02 & -.03 & -.10 & .15 & .13 & .10 & .25 & 1 & -.08 & .04 & .20 & .00 & -.02 \\
\hline $\mathrm{ON}$ & -.10 & -.08 & -.05 & -.04 & .03 & -.00 & .10 & -.04 & .17 & .09 & -.01 & -.09 & .09 & -.14 & -.09 & .00 \\
\hline & & & 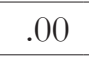 & .02 & -.05 & .04 & .07 & .09 & & .25 & 4 & -.04 & 09 & -.14 & -.01 & -.17 \\
\hline & -.09 & -.14 & .02 & .01 & .10 & -.10 & .19 & -.02 & .11 & .24 & -.00 & -.13 & .11 & -.16 & -.03 & -.02 \\
\hline OPT & -.09 & -.37 & .01 & .09 & .21 & .05 & .15 & -.03 & -.00 & .02 & .37 & .11 & .06 & -.04 & .00 & .00 \\
\hline OGK & -.08 & -.19 & -.07 & -.11 & -.04 & -.12 & .09 & .04 & .13 & .15 & .01 & -.01 & .11 & -.17 & .01 & -.07 \\
\hline & -.02 & .00 & .00 & .16 & .24 & .07 & .18 & -.01 & .19 & .11 & .09 & -.20 & .35 & .02 & -.06 & .10 \\
\hline & -.06 & .00 & -.05 & .10 & .09 & -.00 & .07 & .01 & .05 & .21 & .11 & -.19 & .22 & .13 & -.08 & .10 \\
\hline & -.13 & -.10 & -.08 & .13 & .29 & .04 & .12 & .08 & .01 & .07 & .22 & -.12 & .37 & .07 & .01 & -.00 \\
\hline & -.01 & .19 & .00 & -.09 & .22 & -.02 & .06 & -.06 & .04 & .12 & .03 & -.28 & .08 & -.01 & .10 & .02 \\
\hline & -.15 & -.05 & .03 & .04 & .15 & -.00 & .20 & -.03 & .10 & .05 & -.03 & -.21 & .12 & -.00 & .01 & .10 \\
\hline & & $R_{c}$ & $R_{c}^{2}$ & & $p$ & & & & & & & & & & \\
\hline & & .89 & .80 & \multicolumn{2}{|c|}{440.70} & .00 & & & & & & & & & & \\
\hline
\end{tabular}

(Q4) and gastrointestinal conversion (G11), hypochondria (H13) and phobias (F2).

By solving the characteristic equations of the cross-correlation matrix, as the roots of these equation, two canonical factors were isolated. ,While studying the relations between the systems of normal conative variables and systems of pathological conative variables relatively high canonical correlations were determined for both isolated canonical factors $\left(R_{c}=.83\right.$ and $\left.R_{c}=.79\right)$, and are statistically significant at the $p<.00$ level. The squares of the canonical correlation (Rc2), which explain the common variance of the variables of the two groups of the overall variability of the analyzed systems of variables have a value of $\mathrm{R}_{\mathrm{c}}^{2}=.69$, and $\mathrm{R}_{\mathrm{c}}^{2}=.62$

On the basis of the obtained results contained within the matrix of the canonical structure of normal and pathological conative variables, we can note statistically significant correlations between the applied variables of the first and second canonical factor. The first canonical factor in the space of normal conative variables was defined with the variables of high intelligence - low intelligence (B), higher ego - lower ego $(\mathrm{C})$, bold (parmia) - shy $(\mathrm{H})$, tender-minded (premsia) - tough-minded (I), protension (L) so that it could be defined as the canonical factor which characterizes handball players in relation to intelligence, ego, boldness, tough-mindedness and protension. Since the second canonical factor is defined by variables of self-sufficiency - group adherence (Q2), high self-concept - low self-concept (Q3), tense - relaxed (Q4) and shrewdness - artlessness (N), it can be interpreted as a factor of introspection and shrewdness - artlessness. The first canonical factor in the space of pathological conative variables is defined by the variables of cardiovascular conversion (K10), gastrointestinal conversion (G11), inhibitory conversion (I7) and paranoia (P18), and can be defined as a canonical factor of the effectiveness of the system for the regulation and control of organ function and regulatory function. Since other canonical factors are defined by the variables of ob- 
session (O3), phobia (F2), impulsiveness (N14) and depression (D6), it can be interpreted as a canonical factor of the regulation of reactions such as defense and attack.

Between the systems of anthropometric variables and the system of pathological conative characteristics, no significant relations were determined.

\section{DISCUSSION}

Based on the results contained in the matrix of the canonical structure of anthropometric and normal conative variables (Table 3), we can note a statistically significant correlation between the anthropometric variables and the first canonical factor. The relations between the first canonical factor from the system of anthropometric variables, interpreted as the bipolar canonical factor of the ectomesomorphic morphological type and the first canonical factor from the system of normal conative factors, interpreted as the canonical factor of extrovertness - introvertness and anxiety indicates that handball players of the ectomezomorphic type are characterized at one end by longitudinal measures and on the other by transversal dimensionality of the volume of the femoral region with an increase in the value of the conative variables of extrovertness and decreased anxiety.

The first order factors, $\mathrm{C}$ - ego strength, $\mathrm{G}-$ superego strength $\mathrm{I}$ - tender-tough minded were not significantly related to any of the measured morphological variables. This is a fact which is not completely in accordance with the results, which in this research focusing on the differences in terms of the personality features of athletes and non-athletes, were obtained by Havelka and Lazarević (1981). Namely, they determined that athletes and non-athletes differ significantly in terms of the crystalized intelligence, $B$, ego strength $C$, superego strength $G$, emotional sensitivity I, imaginativeness $\mathrm{M}$ and self-sufficiency Q2. Thus, athletes in relation to non-athletes had a greater crystallized intelligence, were emotionally more stable, had a stronger super ego, harsher

TABLE 3

The canonical structure of anthropometric and normal conative variables.

Fc-1

Fc-1

Anthropometric variables Normal conative factors

\begin{tabular}{cccc}
\hline VIS & -.07 & $\mathrm{~A}$ & -.34 \\
\hline DNO & -.16 & $\mathrm{~B}$ & -.42 \\
\hline DSA & .05 & $\mathrm{C}$ & .11 \\
\hline DST & -.57 & $\mathrm{E}$ & -.21 \\
\hline DRU & -.37 & $\mathrm{~F}$ & .02 \\
\hline BIA & .01 & $\mathrm{G}$ & -.02 \\
\hline BIK & -.08 & $\mathrm{H}$ & -.36 \\
\hline SSA & .34 & $\mathrm{I}$ & -.32 \\
\hline DIR & .30 & $\mathrm{~L}$ & -.45 \\
\hline DIL & .14 & $\mathrm{M}$ & .00 \\
\hline DIK & .30 & $\mathrm{~N}$ & -.18 \\
\hline SST & .01 & $\mathrm{O}$ & -.05 \\
\hline MAS & -.00 & $\mathrm{Q} 1$ & .09 \\
\hline ONA & .03 & $\mathrm{Q} 2$ & -.26 \\
\hline OPO & .14 & $\mathrm{Q} 3$ & -.00 \\
\hline ONT & .08 & $\mathrm{Q} 4$ & -.40 \\
\hline OPT & .28 & & \\
\hline OGK & .00 & & \\
\hline KNN & -.04 & & \\
\hline KNL & -.05 & & \\
\hline KNP & .11 & & \\
\hline KNT & -.11 & & \\
\hline KPT & -.01 & & \\
\hline
\end{tabular}




\section{TABLE 4}

The cross-correlations between normal and pathological conative variables.

\begin{tabular}{lrrrrrrrrrrrr}
\hline & $\mathrm{K} 10$ & $\mathrm{G} 11$ & $\mathrm{I} 7$ & $\mathrm{H} 13$ & $\mathrm{~A} 1$ & $\mathrm{O} 3$ & $\mathrm{~S} 5$ & $\mathrm{~F} 2$ & $\mathrm{~N} 14$ & $\mathrm{~T} 15$ & $\mathrm{P} 18$ & $\mathrm{D} 6$ \\
\hline $\mathrm{A}$ & .07 & -.08 & -.18 & .01 & -.03 & -.05 & -.12 & -.09 & .05 & -.12 & -.06 & -.23 \\
\hline $\mathrm{B}$ & .06 & .04 & .12 & .07 & -.09 & .14 & -.08 & -.02 & -.04 & .12 & .19 & .03 \\
\hline $\mathrm{C}$ & .19 & .15 & .20 & .18 & .06 & .22 & -.06 & .07 & .07 & .20 & .22 & .08 \\
\hline $\mathrm{E}$ & .23 & .26 & .27 & .12 & .35 & -.04 & .14 & .16 & .03 & -.03 & .03 & .30 \\
\hline $\mathrm{F}$ & -.10 & .09 & .19 & -.06 & -.03 & .22 & .05 & -.10 & .10 & .17 & -.04 & .23 \\
\hline $\mathrm{G}$ & .02 & .10 & .10 & .01 & .10 & .03 & .23 & .01 & .04 & .12 & .04 & .07 \\
\hline $\mathrm{H}$ & .12 & .13 & .20 & .00 & .19 & .24 & -.06 & -.01 & -.00 & .10 & .02 & .04 \\
\hline $\mathrm{I}$ & .13 & -.03 & -.08 & -.20 & .18 & .00 & .01 & -.10 & .14 & -.15 & -.03 & .11 \\
\hline $\mathrm{L}$ & .26 & .10 & .14 & .12 & .20 & -.16 & .02 & .18 & -.08 & -.03 & -.10 & -.04 \\
\hline $\mathrm{M}$ & .08 & .05 & -.04 & -.04 & .05 & .20 & .02 & -.00 & .07 & .02 & .04 & .08 \\
\hline $\mathrm{N}$ & .08 & .19 & .25 & .16 & .24 & .08 & .13 & .23 & .25 & -.03 & .04 & .14 \\
\hline $\mathrm{O}$ & -.01 & .09 & -.04 & -.05 & .01 & -.10 & .07 & -.08 & -.13 & -.25 & -.01 & .02 \\
\hline $\mathrm{Q} 1$ & -.11 & -.14 & -.07 & -.24 & .13 & -.29 & -.05 & -.11 & -.20 & -.20 & -.30 & -.05 \\
\hline $\mathrm{Q} 2$ & -.11 & -.07 & -.05 & -.01 & .14 & -.30 & .05 & .07 & .14 & -.08 & -.16 & -.00 \\
\hline $\mathrm{Q} 3$ & -.05 & .28 & .24 & .19 & .16 & .06 & -.04 & .18 & .23 & .15 & .08 & .07 \\
\hline $\mathrm{Q} 4$ & .06 & .31 & .14 & .39 & .10 & -.11 & .17 & .29 & .15 & .01 & .03 & -.02 \\
\hline & & $\mathrm{R}$ & $\mathrm{R}_{c}^{2}$ & $\chi^{2}$ & \multicolumn{1}{c}{$\mathrm{p}$} & & & & & & \\
\hline & & .83 & .69 & 262.94 & .00 & & & & & & \\
\hline & & .79 & .62 & 197.24 & .04 & & & & & & \\
\hline
\end{tabular}

TABLE 5

The canonical structure of normal and pathological conative variables.

\begin{tabular}{|c|c|c|c|c|c|}
\hline \multicolumn{3}{|c|}{ Normal conative factors } & \multicolumn{3}{|c|}{ Patological conative factor } \\
\hline & Fc-1 & Fc-2 & & Fc-1 & $\mathrm{Fc}-2$ \\
\hline A & -.14 & .04 & K10 & .37 & -.07 \\
\hline $\mathrm{B}$ & .28 & -.19 & G11 & .40 & .32 \\
\hline $\mathrm{C}$ & .37 & -.09 & I7 & .49 & .17 \\
\hline $\mathrm{E}$ & .22 & .08 & H13 & .41 & .57 \\
\hline $\mathrm{F}$ & .00 & -.10 & A1 & .19 & .21 \\
\hline G & -.03 & -.01 & $\mathrm{O} 3$ & .16 & -.32 \\
\hline $\mathrm{H}$ & .35 & -.17 & S5 & -.05 & .16 \\
\hline I & -.35 & -.20 & $\mathrm{~F} 2$ & .30 & .55 \\
\hline $\mathrm{L}$ & .31 & .22 & N14 & -.24 & .42 \\
\hline M & -.01 & -.20 & T15 & .20 & .15 \\
\hline $\mathrm{N}$ & .04 & .30 & P18 & .30 & -.05 \\
\hline $\mathrm{O}$ & -.00 & -.13 & D6 & -.01 & -.22 \\
\hline Q1 & -.13 & .03 & & & \\
\hline $\mathrm{Q} 2$ & -.39 & .42 & & & \\
\hline Q3 & .17 & .32 & & & \\
\hline Q4 & .17 & .56 & & & \\
\hline
\end{tabular}


temper and were more emotionally sensitive, more practical, non-self-sufficient and more cooperative. It would seem that handball players, in relation to other athletes are specific in the fact that they are emotionally more stable, with a lower tolerance to frustration and a far lower level of self-control (which is also confirmed by the correlation obtained in this study on the relations between a stronger superego - weaker superego (G) and hypersensitivity (S5), and are thus less conscientious, more realistic in their evaluations, and less self-reliant in solving problems (as seen in the terms of Sten scores).

On the basis of the results obtained and contained within the matrix of the canonical structure of normal and pathological conative variables, we can note statistically significant correlations between the measured variables in the case of the first and second canonical factor. The first canonical factor in the space of normal conative variables can be defined as the canonical factor which characterizes handball players in relation to intelligence, ego, boldness, tough mindedness and protension. The second one can be interpreted as a factor of introspection and tender-mindedness - tough-mindedness.

The first canonical factor in the space of pathological conative variables can be defined as a canonical factor of effectiveness of the system for the regulation and control of organ function and regulatory function, while the second canonical factor can be interpreted as a canonical factor of the regulator of the reactions of defense and attack.

The structure of the correlations indicate that among the handball players with more pronounced warm types of behavior, who are more polite, considerate of others, there was an increase in the scores for depression, as with those who indicated more pronounced liveliness and impulsiveness and expressiveness. Handball players who usually manifest dominant, competitive, assertive or even aggressive behavior face a greater danger of developing one of the conversions (cardiovascular, gastrointestinal or inhibitory) and are more prone to anxiety. Those who are more moral individuals and who have more respect for the rules are more prone to hypersensitivity, and those who are fearless and adventurous score higher for obsession. Those who are suspicious and skeptical indicate a higher inclination towards cardiovascular conversion. The more agile, inquisitive, and discrete participants indicated a greater tendency for inhibitory conversion, anxiety, phobia and impulsive reactions. Those who were more worried, more insecure, often blaming themselves for everything were less prone to aggression. Those who were more open to change, more liberal, more analytical and critical handball players scored lower values for hypochondria, obsession and paranoia. The participants who were more self-satisfied and more self-confident were more prone to obsession, and those with a tendency for perfection, compulsion and self-discipline, who showed a tendency towards more dominant behavior with a lot of self-pity were at a higher risk of gastrointestinal and inhibitory conversion and were more impulsive. Tense, energetic, impatient handball players more frequently develop gastrointestinal conversion, hypochondria and phobias.

In their study, Hošek \& Momirović (1992) dealt with the relationship between the morphological characteristics and pathological conative factors on a sample of 836 men, aged $19-21$, all clinically healthy. Even though these authors indicate that the hypotheses on the connection between morphological characteristics do not a priori need to be rejected, the results obtained in our study indicate that none of the morphological characteristics did not correlate significantly with pathological conative factors. Even Hošek \& Momirović (1992) determined that there was only one statistically significant correlation between the set which measured only seven morphological characteristics (height, weight, biacromial range, average thorax volume, extended upper arm volume, lower leg volume and upper arm skinfold) and the factors included in the test. This difference, even though statistically significant, was very low and the authors themselves considered that these results could be ascribed to the tendency that men with a strong physique have a weaker regulatory function for the reaction of attack, that is, that viewed in the terms of the factors, are more prone aggression and impulsive reactions in situations where they feel threatened and frustrated. Their assumption was not proven justified in our research, primarily because the study included as many as 23 morphological characteristics, at a very high level of selection, considering the fact that the sample consisted of Premiere League handball players. The game of handball at this level requires extremely strong and physically fit players, and thus they need to be in possession of above average anthropomorphological features in relation to the general population.

\section{CONCLUSION}

Effectiveness in performing any kind of human activity is not independent of the features which regulate the modalities of human behavior, handball included. Namely, it is known that certain features of conative space limit effectiveness in various activities, 
directly, and in others indirectly (for example, due to the contaminating effect on some other anthropological features, abilities or characteristics). One cannot exclude the possibility that in some activities the same conative features represent a restrictor, in other a stimulator of effectiveness, especially in situations when the success of a certain activity is at stake. In relation to that, the rule that there are no two participants who could manifest identical structure of any, including conative, features is true, irrespective of their ultimate number. For that reason, knowledge of the complex nature of certain activities, to which the field of conative characteristics belongs, is an important assumption for the operationalization of the aim of any activity, including handball. The results obtained in this study speak of the fact that handball players of the ectomesomorphic type are characterized at the one end, by longitudinal measures and at the other the dimensionality and volume of the femoral region if they are extrovert and non-anxious. In the case of handball players of this rank of competition, who show pronounced signs of warm behavior, who are more polite, considerate of others, there is an increase in the scores for depression, as in the case of those who indicate pronounced liveliness and impulsiveness and expressiveness. Handball players who frequently manifest dominant, competitive, assertive or even aggressive behavior are more prone to anxiety. Those who have higher morals and more respect for the rules are more prone to hypersensitivity, and those who are fearless and adventurous score higher values on the score for obsession. Tense, energetic, impatient handball players more frequently develop gastrointestinal conversion, hypochondria and phobia.

\section{REFERENCES}

Cattell, R. B., Eber, H. W., \& Tatsuoka, M. (1970). Handbook for the Sixteen Personality Factor Qustionnaire. Champaign, ILL: Institute for Personality and Ability Testing.

Gabrijelić, M. (1977). Manifestne i latentne dimenzije vrbunskih sportista nekih momčadskih sportskib igra u motorickom, kognitivnom i konativnom prostoru

[Manifest and latent dimensions of elite athletes some TEAM sport plays in motor, cognitive and cognitive space]. Unpublished doctoral dissertation, University of Zagreb, Fakultet za fizičku kulturu.

Havelka, N., \& Lazarević, Lj. (1981). Sport i ličnost [Sport and personality]. Belgrade, RS: Sportska knjiga.
Herdis, L., Deabler, E., Hartl, M., \& Willis, C. A. (1973). Physique and personality: somatotype and the 16 PF. Perceptual and Motor Skills, 36, 927-933. doi: 10.2466/pms.1973.36.3.927

Hol, S. K., \& Lindzi, G. (1983). Teorije ličnosti [Theories of personality]. Beograd, RS: Nolit. Hošek, A., \& Momirović, K. (1992). Prilog poznavanju odnosa između morfoloških karakteristika i osobina ličnosti [Contribution to the knowledge of the relationship between morphological characteristics and personality traits]. Psibologija, 3-4, 36-42.

Ilić, S. (1993). Relacije bazično-motoričkih i situacionomotorickih sposobnosti u rukometu [Relationships basic-motor and situational-motor skills in handball]. Unpublished master's thesis, University of Belgrade, Fakultet fizičke kulture.

Katel, R. B. (1978). Naučna analiza ličnosti [Scientific analysis of personality]. Beograd, RS: BIGZ.

Kretschmer, E. (1970). Physique and character. New York, NY: Cooper Square.

Malacko, J., \& Popović, D. (2001). Metodologija kineziološko antropoloških istraživanja [Methodology of Kinesiology and anthropological research]. Leposavić, RS: Fakultet za fizičku kulturu.

Momirović, K. (1971). Struktura i mjerenje patoloških konativnih faktora [Structure and measurement of cognitive pathological factors]. Zagreb, HR: Republički zavod za zapošljavanje.

Pajević, D. (2003). Psibologija sporta i rekreacije [Psychology of sport and recreation]. Laktaši, BA: Grafomark.

Pokrajac, B. (1983). Telesni i motorickei status rukometaša u odnosu na takmičarski nivo i komparativna analiza sa sportistima drugih sportskih igara [Physical and motor status of handball in relation to the competitive level and comparative analysis with athletes of other sports games]. Unpublished doctoral dissertation, University of Belgrade, Fakultet fizičkog vaspitanja.

Popović, D., \& Simonović, M. (2008). Psihologija $i$ psibologija sporta [Psychology and psychology of sport]. Leposavić, RS: Fakultet za sport i fizičko vaspitanje.

Popović-Ilić T., Stanković V., Vitošević B., \& Ilić S. (2010). Struktura morfoloških dimenzija vrhunskih sportista [Structure of the morphological dimensions of elite athletes]. Praxis medica, 38(3-4), 63-70.

Powell, A., \& Royce, J.R. (1981). An overwiev of a multifactor - system theoory of personality and 
social differences: The factor and system models and the hiearchical factor structure of individuality. Journal of Personality and Social Psychology, 41(4), 818-829. doi: 10.1037/00223514.41.4.818

Sheldon, W. H., \& Stevens, S. S. (1942). The varieties of temperament: a psychology of constitutiond differences. New York, NY: Harper.

Srhoj, V., Marinović, M., \& Rogulj, N. (2002). Position specific morphological characteristics of top-level male handball players. Collegium antropologicum, 26(1), 219-227. PMid: 12137302

Stanković, V. (2000). Testiranje i primena programa za utvrdivanje strukture i razlika u medusobno povezanim prostorima kod rukometaša u toku jednogodišnjeg trena:̌nog procesa [Testing and implementation of programs for the determination of structure and the difference in the interrelated areas of the handball players during a one-year training process]. Unpublished doctoral dissertation, University of Prišstina, Fakultet za fizičku kulturu.

Stanković, V. (2001). Osnove primenjene kineziologije [Basic of applied kinesiology]. Leposavić, RS: Fakultet za fizičku kulturu.

Stanković, V., \& Malacko, J. (2008). Relations between systems of motor, cognitive and conative variables of top-class handball players. Kinesiologia Slovenica, 3(14), 33-44.

Stanković, V., Malacko, J., \& Doder, D. (2009). The differences in morphological characteristics among top handball, basketball and football players. Acta Kinesiologica, 3(2), 90-94.

Stanković, V., Malacko, J., \& Doder, D. (2011). Comparative analiysis of factor structures of latent variables of pathological connate characteristics in case of handball players belonging to different competition ranks. Acta Kinesiologica, 5(2), 58-62.

Stanković V., \& Popović M. (2011). Identifikacija morfoloških karakteristika povezanih sa horizontalnim osovinama rukometaša i fudbalera [Identification of morphological characteristics associated with the horizontal axis and handball players]. Praxis medica, 39(1-2), $55-58$.

Szirovicza, L., Momirović, K., Hošek, A., \& Gredelj, M. (1980). Latentne morfološke dimenzije određene na temelju faktorskog $\mathrm{i}$ taksonomskog modela u standardiziranom image prostoru [Latent morphological dimensions determined on the basis of factor and taxonomic models in a standardized image space]. Kineziologija, 10, 15-20.

Šentija, D, Matković B, Vuleta D, Tomljanović M, \& Džaj, I. (1997). Funkcionalne sposobnosti vrhunskih rukometaša i rukometašica [Functional abilities of top handball players]. In D. Milanović D and S. Heimer S. (Eds.), Dijagnostika trenirnosti sportaša (pp. 36-39). Zagreb, HR: Fakultet za fizičku kulturu.

Šibila, M., \& Pori, P. (2009). Position-related differences in selected morphological body characteristics of top-level handball players. Collegium antropologicum, 33(4), 1079-1086. PMid: 20102051

Vrbik, I., Čižmek, A., \& Gruić I. (2011).

Morfološke karakteristike između igračkih pozicija kod vrhunskih rukometaša [Morphological characteristics between playing positions in elite handball players]. Hrvatski športskomedicinski vjesnik. 26(2), 94-99.

Received: October 7, 2013

Revision received: December 12, 2013

Accepted: December 21, 2013

Correspondence to:

Veroljub Stanković, $\mathrm{PhD}$

Fakultet za sport i fizičko vaspitanje

Univerzitet u Prištini

Dositeja Obradovića bb 38218 Leposavić Serbia

Phone: 00381648904600

E-mail: veroljub.stankovic@pr.ac.rs 